\title{
CLADOCERA CHYDORIDAE OF HIGH ALTITUDE WATER BODIES (SERRA DA MANTIQUEIRA), IN BRAZIL
}

\author{
SANTOS-WISNIEWSKI, M. J., ${ }^{1}$ ROCHA, O., ${ }^{1}$ GÜNTZEL, A. M. ${ }^{1}$ and \\ MATSUMURA-TUNDISI, T. ${ }^{2}$ \\ ${ }^{1}$ Departamento de Ecologia e Biologia Evolutiva, Universidade Federal de São Carlos, C. P. 676, \\ CEP 13565-905, São Carlos, SP, Brazil \\ ${ }^{2}$ Instituto Internacional de Ecologia, Rua Bento Carlos, 750, CEP 13560-000, São Carlos, SP, Brazil \\ Correspondence to: Maria José Santos-Wisniewski, Departamento de Ecologia e Biologia Evolutiva, \\ C. P. 676, CEP 13565-905, São Carlos, SP, Brazil, e-mail: czw@uol.com.br \\ Received February 22, 2002 - Accepted April 9, 2002 - Distributed November 30, 2002
}

(With 2 figures)

\begin{abstract}
The diversity of species of Cladocera, Chydoridae in the water bodies belonging to the water management unity of Serra da Mantiqueira, was studied inside the BIOTA/FAPESP Program. A total of 21 water bodies were analyzed and the sampling was carried out between $9^{\text {th }}$ and $11^{\text {th }}$ September, 1999 . Horizontal and vertical net hauls were taken at littoral and limnetic region in each lake. Most water bodies in Serra da Mantiqueira unity are small, shallow, and densely colonized by macrophytes. Most species of Cladocera found belong to the Chydoridae family, being typical inhabitants of the littoral zone, living associated with macrophytes. A total of 12 species were found, 9 of the subfamily Aloninae and 3 Chydorinae. In more than half of the water bodies the relative abundance of chydorids reached $100 \%$, and they were dominant in most of the others, with few exceptions. Alona rustica was the most frequent species, occurring in $62 \%$ of the water bodies. The results evidenced the importance of the littoral zone as propitious habitats for the species of Chydoridae and contributing significantly to the diversity of Cladocera as a whole.
\end{abstract}

Key words: Cladocera, Chydoridae, zooplankton diversity.

\section{RESUMO}

\section{Cladocera Chydoridae de corpos d'água de grande altitude (Serra da Mantiqueira)}

A diversidade de espécies de Cladocera Chydoridae da unidade de gerenciamento dos recursos hídricos (UGRHI) da Serra da Mantiqueira foi estudada, como parte do Programa BIOTA/FAPESP. Foram analisadas amostras de 21 corpos d'água desta unidade de gerenciamento e as coletas foram realizadas no período de 9 a 11/9/99. Para a análise da comunidade zooplanctônica foram coletadas amostras por meio de arrastos horizontais e verticais na região limnética e na região litorânea. Os corpos d'água da UGRHI da Serra da Mantiqueira são pequenos, de pouca profundidade e densamente colonizados por macrófitas aquáticas. As espécies de Cladocera encontradas são típicas de região litorânea, vivendo associadas a macrófitas, isto é, representantes da família Chydoridae. Em relação à abundância relativa, esta família representou quase $100 \%$ do total de Cladocera da maior parte dos corpos d'água e, quanto à riqueza de espécies, representou mais da metade das espécies de Cladocera. A espécie Alona rustica foi a mais freqüente, ocorrendo em $62 \%$ dos corpos d'água. Os resultados obtidos comprovam que nos ambientes estudados a região litorânea desempenha papel importante, favorecendo o desenvolvimento de condições especiais para o crescimento de espécies de Chydoridae e contribuindo significativamente para a diversidade total dos Cladocera.

Palavras-chave: Cladocera, Chydoridae, diversidade do zooplâncton. 


\section{INTRODUCTION}

For most aquatic ecosystems, the littoral region represents the interface or the contact zone with terrestrial ecosystems and plays an important role, sometimes functioning as a filter. This region is characterized by high productivity and heterogeneity of habitats, favoring the development of a diversified zooplankton community. Among the organisms inhabiting the littoral region the members of the family Chydoridae, belonging to the Cladocera group are represented by a major part of the species present. These organisms live usually associated with macrophytes, periphyton or sediment and they contribute significantly to the biomass and productivity of the water bodies. They occupy a key position in food chains converting organic matter used for its own growth and also making it available to higher trophic levels. They can also be indicators of the trophic state of the water bodies, because they quickly respond to the changes in environmental variables (Duigan \& Kovach, 1991). They can also be used in the reconstruction of the past history of the aquatic ecosystem, considering that they have many fossil remains well preserved in the sediment (Whiteside, 1970).

The present work has analysed the diversity of species of the family Chydoridae in Serra da Mantiqueira, one of the 22 Water Resources Management Unities of São Paulo State.

\section{MATERIAL AND METHODS}

Twenty one water bodies were sampled, in the districts of Campos do Jordão and São José dos Alpes between $22^{\circ} 41.405^{\prime} \mathrm{S}$ and $22^{\circ} 46.229^{\prime} \mathrm{S}$ and between $45^{\circ} 25.156^{\prime} \mathrm{W}$ and $45^{\circ} 34.110^{\prime} \mathrm{W}$ (Fig. 1) at altitudes varying from 1,800 to $1,920 \mathrm{~m}$.

The total management unity has a drainage basin of $642 \mathrm{~km}^{2}$ and the main tributaries are the rivers Sapucaí, Sapucaí-Mirim, Prata and Paiol Grande stream. Because of the high altitude, the water temperatures are low and there is great change of slopes in the streams, creating rapid waters and small falls. Most water bodies sampled in this region are small lakes, reservoirs and streams, of small depth (varying from 0.5 a 5.5 $\mathrm{m})$ and with plenty macrophyte vegetation at the littoral zone. The small reservoirs were constructed for various uses such as hydroelectric generation (Santa Isabel and Fojo reservoir), fish farming (Horto Florestal ponds) and also for recreation. Some are located among the Atlantic Forest reserve of Horto Florestal whereas others as Lavrinhas 1 and Lavrinhas 2 reservoirs are in private properties.

Sampling was carried out during the period between $09^{\text {th }}$ and $11^{\text {th }}$ of September, 1999.

\section{PHYSICAL AND CHEMICAL CHARACTERIZATION}

For in situ chemical and physical analysis of the water a U10 Horiba water-quality checker was used, measuring, $\mathrm{pH}$, conductivity, temperature oxygen. Transparency was evaluated by Secchi disk readings. Concentrations of chlorophyll $a$, suspended material, and nutrients were analyzed.

\section{Quantitative and qualitative analyses of the family Chydoridae}

Samples were taken by means of combined horizontal and vertical hauling in the limnetic and littoral regions near macrophyte banks. Volumes of at least $100 \mathrm{~L}$ in quantitative sampling and over $300 \mathrm{~L}$ in qualitative sampling were filtered in a $68 \mu \mathrm{m}$-mesh net. The samples were immediately preserved with a $4 \%$ neutralized formaldehyde. During the quantitative analysis a sub-sample with varying volume was analyzed (from $5 \mathrm{ml}$ to the whole sample in the case of very low concentrations), whereas for the qualitative analysis the total sample was analyzed.

The preparations of the head shields for the visualization of the cephalic pores were performed according to the procedure described by Megard (1965). The organisms were identified using the following specialized literature: Bergamin, 1932; Edmondson, 1959; Scourfield \& Harding, 1966; Smirnov, 1974, 1996; Young, 1998; Elmoor-Loureiro, 1997; Paggi, 1972; Duigan, 1992; Dumont \& SilvaBriano, 1998; Rajapaksa \& Fernando, 1987a; Duigan \& Murray, 1987; Rajapaksa \& Fernando, 1987b; Paggi, 1980; Smirnov, 1998; Frey, 1982; Alonso, 1987; Pennak, 1989; Olesen, 1996; Biraben, 1939; Olivier, 1962; Smirnov \& Timms, 1983; Sinev1999. 


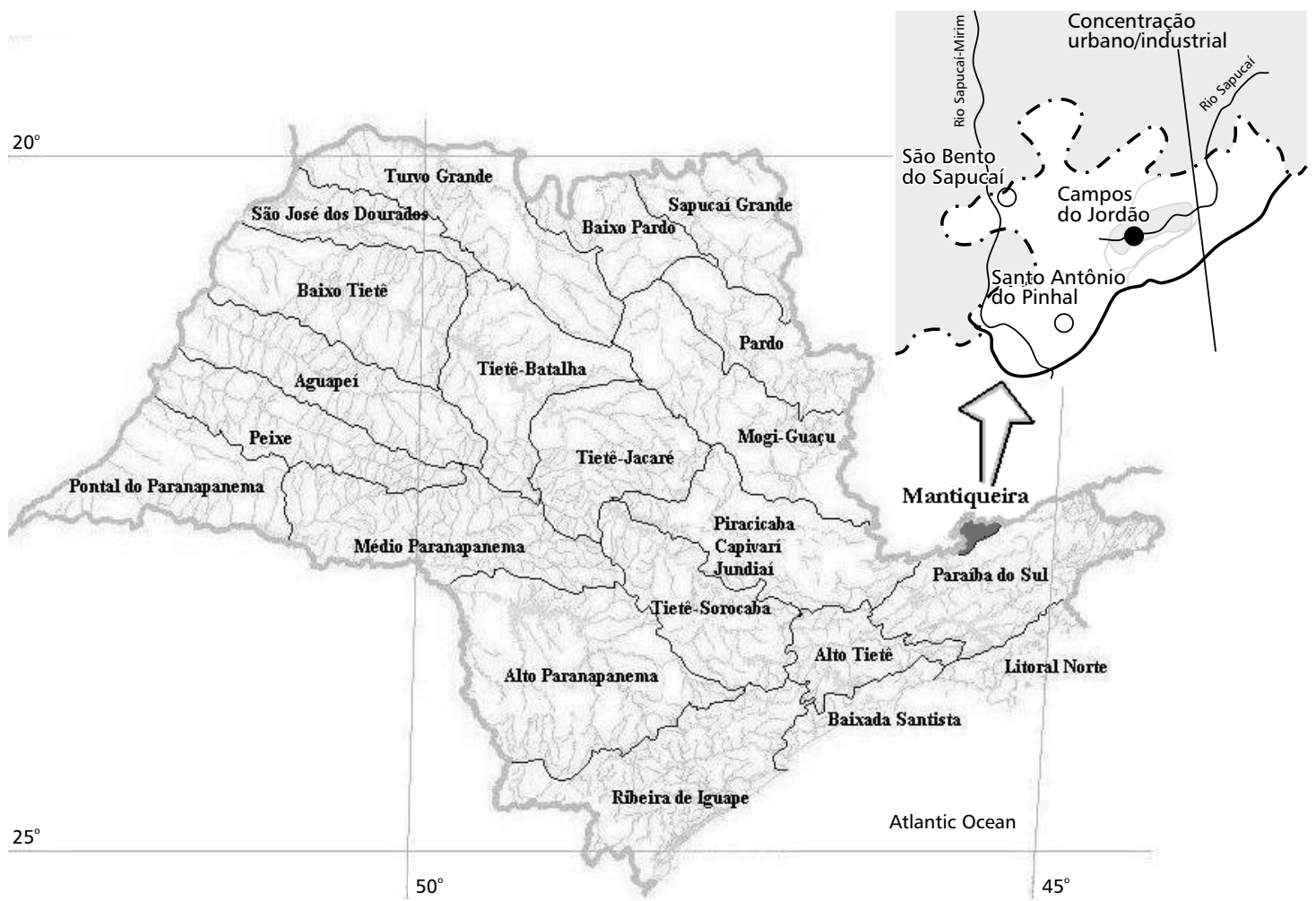

Fig. 1 - Map of São Paulo State showing the 22 Water Resources Management Unity, highlighting the unity Serra da Mantiqueira focused on this study. Source: http://www.biota.org.br.

\section{RESULTS}

Table 1 shows the results obtained for the physical and chemical variables analysed. The trophic state of the water bodies sampled varied from oligotrophic up to eutrophic, being Lavrinhas 2 the most eutrophic. It has the highest concentrations of nutrients and suspended matter, as a consequence of the large number of aquatic birds inhabiting it. The most oligotrophic was Fojo Reservoir. This water body is used for supplying water to Campos do Jordão City and it is well preserved. The Reservoir has low nutrient and chlorophyll $a$ concentrations, as well as low conductivity.

A marginal pond to Fojo Reservoir was also sampled for biological communities. In general the $\mathrm{pH}$ of the various ponds was slightly acid (4.3 to 6.7), had high concentrations of dissolved oxygen (5.8 to $10.9 \mathrm{mg} / \mathrm{L}$ ) and low values of suspended matter.
In relation to the relative abundance of organisms, the family Chydoridae represented almost $100 \%$ of the total of Cladocera in most water bodies (Fig. 2). Exceptions were the sampling station 1 of Itapeva Lake (limnetic region), lakes 3 and 4 of Horto Florestal and Vila Inglesa Lake where the species belonging to the family Bosminidae were the most abundant. Among the Chydorydae the species Alona rustica was the dominant in most water bodies.

The family Chydoridae had the highest richness of species. A total of 12 species were found among all the water bodies sampled, 9 species belonging to the subfamily Aloninae and 3 to the subfamily Chydorinae. Among the Aloninae, the most frequent species was Alona rustica that was found in $55 \%$ of the water bodies and among the Chydorinae, the species Chydorus pubescens occurring in $35 \%$ of them (Table 2 ). 
The highest richness of species were found in a marginal pond near Fojo Reservoir followed by lake Pico ltapeva and Trutas Lake. The last lake is small, shallow, richly vegetated, $400 \mathrm{~m}^{2}$ large. Seven species were found in this pond, 6 members of the subfamily Aloninae (Acroperus harpae, Alona rustica, A. monacantha, Alona quadrangularis, Karualona sp.) and one from the Chydorinae (Chydorus pubescens).

Species of the family Bosminidae were the most abundant organisms in Itapeva Lake, however the family Chydoridae contributed with a larger number of species (6 species).

Species of Chydoridae were not found in Lakes 4 and 5 of Horto Florestal, the forest reserve of Campos do Jordão district, nor in Fonte da Hospedaria, a fountain. Cladocera in these lakes were dominated by species of the family Bosminidae. Riacho das Trutas (Trout stream) and Instituto de Pesca Stream, both lotic environments, had low Chydoridae species richness, 2 and 3 respectively.

\section{DISCUSSION}

The water bodies of Serra da Mantiqueira unity are mostly small, shallow and heavily colonized by macrophytes. The presence of abundant macrophytes creates adequate substrates for chydorids, typical inhabitants of the littoral region. Among all the families of Cladocera the Chydoridae had the highest richness of species and relative abundances for most lakes, evidencing its importance regarding freshwater invertebrates diversity. Only few lakes with no aquatic plants were not colonized by species of this family.

Despite the evident importance of the Chydoridae family in the zooplankton of the water bodies surveyed, its total richness at Serra da Mantiqueira unity is smaller than that found in other regions, as for example the Alto Tietê unity where a total of 21 species belonging to this family were recorded (Santos-Wisniewski et al., in preparation). A greater heterogeneity of habitats is the probable cause for the high richness found in Alto Tietê, which comprises from small ponds up to very large reservoirs, very oligotrophic up to hyper-eutrophic water bodies, thus providing a number of different environments and opportunities to a variety of species having diverse requirements. At Serra da Mantiqueira Unity, on the other hand, the many small ponds are closely located and have more similar conditions, perhaps the reason for the great similarity in the species composition, resulting lowest total richness.

Among the species found it was not possible to characterize any species assemblage that could be considered characteristic of a particular type of water body. The species Alona rustica was the most widespread regarding the spatial distribution in the area of study. It seems to be a tolerant species, occurring in environments from the very oligotrophic up to the eutrophic ones (Duigan, 1992).

Among the Chydoridae there is a number of species considered species-complex, of uncertain taxonomical position. Some of the species found in Serra da Mantiqueira fall in this category, as Acroperus harpae and Chydorus sphaericus. Several authors believe they are not cosmopolitan and that the forms occurring in different continents will probably be distinct species. Careful and detailed re-descriptions are under preparation for the species found in São Paulo State.

In this inventory, two species of the so called Alona costata group were found which are Alona rustica and Alona setigera. According to Sinev (1999) there exist 8 species belonging to the complex Alona costata: Alona costata in Europe; Alona setigera in Australia, Tasmânia and Indonesia; Alona cheni in India; Alona rustica in Europe and East Siberia (although already recorded in Brazil by Elmoor-Loureiro, 1997); Alona hudeci in Venezuela; Alona bicolor in North America, and two species Alona fabricii and Alona muelleri in Groenland. The species Alona setigera was recorded for Brazil for the first time by SantosWisniewski et al. (2001). This species initially described by Brehm (1931) as a variety of Alona guttata (A. guttata setigera) occurring in New Zealand. Smirnov \& Timms (1983) registered this species in Australia, describing it as Biapertura setigera. Later on it was found a great similarity between Alona setigera and Alona costata, differing only in the number of head pores (two pores in Alona setigera and three in Alona costata) (Sinev, 1999), an argument against the distinction the genus Biapertura and Alona. Until recently Alona setigera was known only from New Zealand, Australia, Tasmania and Indonesia, the record of this species in Serra da Mantiqueira makes it the second record of the species in Brazil. A close check on its characteristics evidenced that Alona setigera is closely related to Alona costata. 
TABLE 1

Values obtained for physical and chemical variables in the water bodies of Serra da Mantiqueira, in September, 1999. $\mathrm{L}=$ lake; $\mathrm{R}=$ reservoir; $\mathrm{S}=$ stream; $\mathrm{Nt}=$ total nitrogen; $\mathbf{I n} .=$ inorganic; $\mathbf{P t}=$ total phosphorus; $\mathbf{I M}=$ inorganic matter; $\mathbf{O M}=$ organic matter, Chl. = chlorophyll; Cond. = conductivity; DO = dissolved oxygen; and TSI $=$ trophic state index.

\begin{tabular}{|c|c|c|c|c|c|c|c|c|c|c|c|c|}
\hline \multirow{2}{*}{ Site } & \multirow{2}{*}{$\begin{array}{l}\mathrm{NO}_{3}^{-} \\
(\mu \mathrm{g} / \mathrm{L})\end{array}$} & \multirow{2}{*}{$\begin{array}{l}\mathrm{NH}_{4}{ }^{+} \\
(\mu \mathrm{g} / \mathrm{L})\end{array}$} & \multirow{2}{*}{$\begin{array}{c}\mathrm{Nt} \\
(\mu \mathrm{g} / \mathrm{L})\end{array}$} & \multirow{2}{*}{$\begin{array}{l}\mathrm{PO}_{4} \text { in. } \\
(\mu \mathrm{g} / \mathrm{L})\end{array}$} & \multirow{2}{*}{$\begin{array}{c}\mathbf{P t} \\
(\mu \mathrm{g} / \mathrm{L})\end{array}$} & \multirow{2}{*}{$\begin{array}{c}\mathrm{IM} \\
(\mathrm{mg} / \mathrm{L})\end{array}$} & \multirow{2}{*}{$\begin{array}{c}\text { OM } \\
(\mathrm{mg} / \mathrm{L})\end{array}$} & \multirow{2}{*}{$\begin{array}{l}\text { Chlor. } \\
(\mu \mathrm{g} / \mathrm{L})\end{array}$} & \multirow{2}{*}{\begin{tabular}{|c|} 
Cond. \\
$(\mu \mathrm{Si} / \mathrm{cm} 2)$
\end{tabular}} & \multirow{2}{*}{$\begin{array}{c}\text { DO } \\
(\mathrm{mg} / \mathrm{L})\end{array}$} & \multicolumn{2}{|c|}{ Carlson indices } \\
\hline & & & & & & & & & & & TSI (Chlor) & TSI (Pt) \\
\hline Fojo R. & 37.7 & 44.6 & 274.3 & 0.8 & 3.4 & & & 0.5 & 12.0 & 9.2 & 23.2 & 21.2 \\
\hline Lambaris L. & 67.7 & 30.6 & 224.1 & 4.6 & 6.4 & 3.4 & 2.6 & 0.0 & 120.0 & 8.0 & & 30.3 \\
\hline Ninfóides L. & 12.0 & 15.5 & 388.9 & 2.6 & 27.4 & 1.2 & 7.0 & 14.4 & 70.0 & 6.8 & 56.7 & 50.9 \\
\hline H. Florestal $1 \mathrm{~L}$. & 57.1 & 30.6 & 374.1 & 2.4 & 21.3 & & & 9.8 & 80.0 & 7.0 & 53.0 & 47.3 \\
\hline H. Florestal $2 \mathrm{~L}$. & 38.7 & 40.7 & 311.4 & 5.6 & 6.6 & 10.0 & 9.0 & 4.1 & 70.0 & 5.8 & 44.5 & 30.7 \\
\hline H. Florestal $3 \mathrm{~L}$. & 12.2 & 37.6 & 410.0 & 2.3 & 25.5 & 8.4 & 13.6 & 13.4 & 60.0 & 7.4 & 56.0 & 49.8 \\
\hline H. Florestal $4 \mathrm{~L}$. & 123.0 & 68.3 & 436.1 & 21.0 & 21.9 & 1.2 & 5.2 & 1.7 & 110.0 & 7.8 & 35.8 & 47.7 \\
\hline H. Florestal $5 \mathrm{~L}$. & 117.5 & 63.7 & 443.2 & 19.7 & 25.2 & 1.6 & 6.4 & 6.3 & 110.0 & 8.3 & 48.7 & 49.7 \\
\hline Sta. Isabel R. & 19.1 & 8.1 & 368.9 & 2.3 & 30.0 & 0.8 & 3.0 & 25.8 & 70.0 & 10.9 & 62.4 & 52.2 \\
\hline Trutas S. & 46.4 & 407.3 & 567.2 & 34.8 & 102.4 & 0.6 & 2.2 & 1.6 & 50.0 & 7.7 & 35.2 & 69.5 \\
\hline Tundra L. & 59.7 & 15.9 & 218.2 & 2.7 & 5.0 & 3.2 & 2.6 & 1.3 & 64.0 & 7.8 & 33.1 & 26.9 \\
\hline Lavrinhas 1 L. & 52.8 & 30.3 & 269.1 & 2.8 & 5.6 & 2.0 & 4.3 & 1.9 & 120.0 & 7.4 & 36.9 & 28.4 \\
\hline Lavrinhas $2 \mathrm{~L}$. & 9.6 & 10.0 & 1219.5 & 13.0 & 181.0 & 30.0 & 108.0 & 234.1 & 50.0 & 9.8 & 84.1 & 77.6 \\
\hline Inst. Pesca S. & 70.1 & 7.7 & 231.9 & 2.0 & 4.0 & 0.4 & 1.6 & 0.3 & 90.0 & 10.2 & 19.7 & 23.6 \\
\hline Pico Itapeva R. & 8.4 & 19.0 & 295.8 & 1.1 & 5.9 & 1.7 & 2.0 & 8.1 & 40.0 & 9.5 & 51.0 & 29.3 \\
\hline \begin{tabular}{|l|} 
Hípica 1 L. \\
\end{tabular} & 42.7 & 13.9 & 283.4 & 1.5 & 6.6 & 1.0 & 1.8 & 1.1 & 60.0 & 8.9 & 31.1 & 30.8 \\
\hline Hípica 2 L. & 29.0 & 13.9 & 198.0 & 1.4 & 4.1 & 4.0 & 3.7 & 4.5 & 150.0 & 6.9 & 45.3 & 24.1 \\
\hline Vila Inglesa L. & 65.3 & 96.7 & 422.4 & 1.7 & 13.8 & 3.0 & 5.0 & 0.8 & & & 28.9 & 41.2 \\
\hline
\end{tabular}

$\square$ Chydoridae Stebbing 1902 Family
$\square$ Daphniidae Straus 1820 Family
$\mathbb{M}$ Moinidae Family
$\square$ Sididae Baird 1850 Family

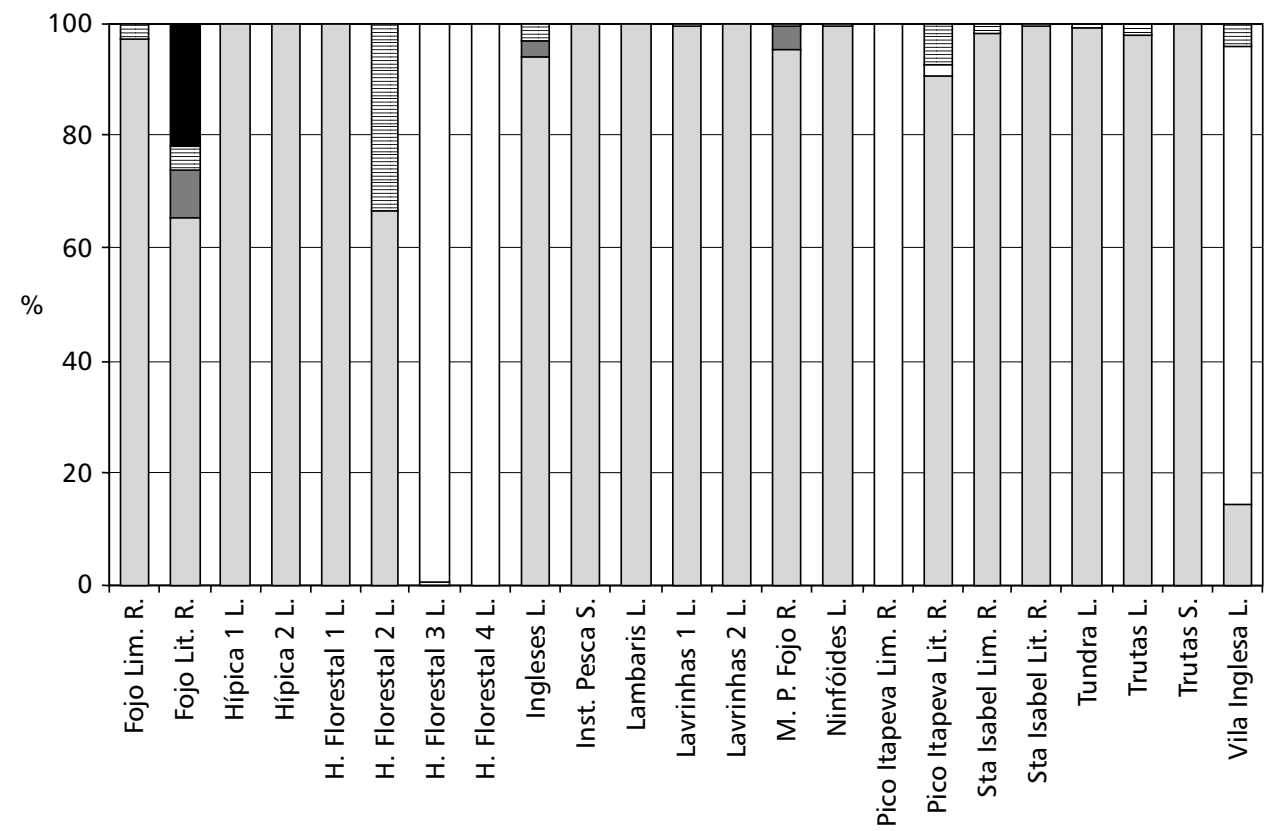

Fig. 2 - Relative abundance of Cladocera families in the water bodies of Serra da Mantiqueira unity. 
TABLE 2

Occurrence of the Cladocera Chydoridae species in the water bodies of Serra da Mantiqueira unity.

\begin{tabular}{|c|c|c|c|c|c|c|c|c|c|c|c|c|c|c|c|c|c|c|c|c|}
\hline & 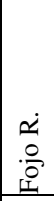 & 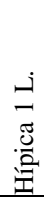 & 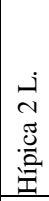 & 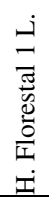 & 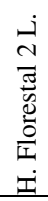 & 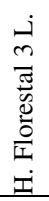 & 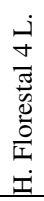 & 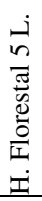 & 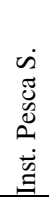 & 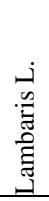 & 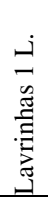 & 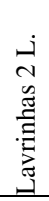 & 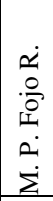 & 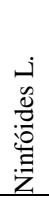 & 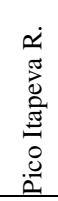 & 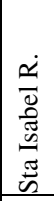 & 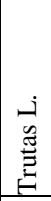 & 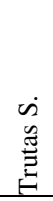 & 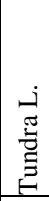 & 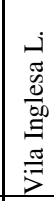 \\
\hline \multicolumn{21}{|l|}{ Chydoridae Family } \\
\hline \multicolumn{21}{|l|}{ Aloninae Subfamily } \\
\hline Acroperus harpae & + & & & & & & & & & + & & & + & & & + & + & & + & \\
\hline Alona affinis & & & & & & & & & & & + & + & & & & & + & & & \\
\hline $\begin{array}{l}\text { Alona guttata } \\
\text { tuberculata }\end{array}$ & + & & & & & & & & & + & + & + & & + & + & & + & & & + \\
\hline Alona intermedia & & + & + & & + & & & & & & & & & & & & + & + & & + \\
\hline Alona karua & & & & & + & & & & & & & & + & + & & + & + & & + & + \\
\hline Alona monacantha & & & & & & & & & & & & & + & & & & + & & & \\
\hline Alona quadrangularis & + & & & & + & & & & & & & + & + & & + & & & & & \\
\hline Alona rustica & + & + & + & + & + & & & & + & + & & & + & + & + & + & & & & + \\
\hline Alona setigera & & & & & & & & & & + & + & + & & & & + & + & + & + & \\
\hline Camptocercus daday & & + & + & & & & & & + & & & & & + & + & & & & & + \\
\hline \multicolumn{21}{|l|}{ Chydorinae Subfamily } \\
\hline Alonella chlathratula & & & & & & & & & & & + & & & & & & & & & \\
\hline Alonella dadayi & & & & + & + & + & & & & & & & & + & + & & & & & \\
\hline Chydorus pubescens & & & & & & & & & & & & & + & & + & + & & & & + \\
\hline
\end{tabular}

It can be concluded that chydorids were representative of the invertebrate fauna at Serra da Mantiqueira unity and made up an important fraction of the zooplankton community in these high altitude lakes of Brazil.

Aknowledgments - The authors thank FAPESP for financial support for the project "Zooplanktonic biodiversity and degradation status of continental water ecosystems in São Paulo State", a part of the project BIOTA/FAPESP - The Virtual Institute of Biodiversity (www.biotasp.org.br) and to the PRONEX/CNPq for the financial support provided.

\section{REFERENCES}

ALONSO, M., 1987, Morphological differentiation of two new Ephemeroporus species (Cladocera, Chydoridae) belonging to the barroisi complex: E. margalefi and E. epiaphantoii, in Spain. Hydrobiologia, 145: 131-46.

BERGAMIN, F., 1932, Estudo sistemático dos Cladocera das águas do município de São Paulo. Tese de Doutorado, Faculdade de Medicina de São Paulo. Empreza Graphica da Revista dos Tribunaes, São Paulo, 58p.
BIRABEN, M., 1939, Los Cladoceros de la familia Chydoridae. Physis, XVII: 651-70.

BREHM, V., 1931, Cladoceran aus Neuseeland. Arch. Hydrobiol., 23: 491-501.

DUIGAN, C. A., 1992, The ecology and distribution of the litoral freshwater Chydoridae (Branchiopoda, Anomopoda) of Ireland, with taxonomic comments on some species. Hydrobiologia, 241: 1-70.

DUIGAN, C. A. \& KOVACH, W. L., 1991, A study of the distribution and ecology of littoral freshwater Chydorid (Crustacea, Cladocera) communities in Ireland using multivariate analyses. J. Biogeogr., 18: 267-280.

DUIGAN, C. A. \& MURRAY, D. A., 1987, A contribution to the taxonomy of $C$. sphaericus sens. lat. (Cladocera, Chydoridae). Hydrobiologia, 145: 113-24.

DUMONT, H. J. \& SILVA-BRIANO, M., 1998, A reclassification of the anomopod families Macrothricidae and Chydoridae, with the creation of a new suborder, the Radopoda (Crustácea: Brachiopoda). Hydrobiologia, 384: 119-49.

EDMONDSON, W. T., 1959, Freshwater Biology. Second edition. John Wiley \& Sons. Inc., USA, 1248p.

ELMOOR-LOUREIRO, L. M. A., 1997, Manual de identificação de cladóceros límnicos do Brasil. Universa, Brasília, 156p. 
FREY, D. G., 1982, Relocation of Chydorus barroisi and related species (Cladocera, Chydoridae) to a new genus and description of two new species. Hydrobiologia, 86: 231-269.

MEGARD, R., 1965, A Chemical technique for disarticulating the exoskeletons of Chydorid Cladocera. Crustaceana, 9: 208-211.

OLESEN, J., 1996, External morphology and phylogenetic significance of dorsal/neck organ in the Conchostraca and head pores of the cladoceran family Chydoridae (Crustacea, Branchiopoda). Hydrobiologia, 330: 213-326.

OLIVIER, S. R., 1962, Los cladoceros argentinos. Rev. del Museo de La Plata República Argentina, p. 173-329.

PAGGI, J. C., 1980, Aportes al conocimiento de la fauna Argentina de cladoceros. II: Euryalona fasciculata Daday 1905 y Euryalona occidentalis Sars 1901. Rev. Asoc. Cienc. Nat. Litoral, 11: 145-60.

PAGGI, J. C., 1972, Nota sistemática acerca de algunos cladoceros del gênero Chydorus Leach, 1843, de la República Argentina. Physis, Tomo XXXI, 82: 223-236.

PENNAK, R. W., 1989, Freshwater invertebrates of the United States: Protozoa to Mollusca. 3. ed. John Wiley \& Sons, Inc., New York, 628p.

RAJAPAKSA, R. \& FERNANDO, C. H., 1987a, A description of Euryalona orientalis (Daday, 1898), with a consideration of the other species in the genus Euryalona (Cladocera: Chydoridae). Hydrobiologia, 150: 75-90.

RAJAPAKSA, R. \& FERNANDO, C. H., 1987b, Redescription and assignment of Alona globulosa Daday 1898 to a new genus Notoalona and a description of Notoalona freyi sp. nov. Hydrobiologia, 144: 131-53.
SCOURFIELD, D. J. \& HARDING, J. P., 1966, A key to the British Freshwater Cladocera with notes on their ecology. Freshw. Biol. Association. Scientific Publication, n. 5. 3. ed. $55 \mathrm{p}$.

SINEV, A. Y., 1999, Alona costata Sars, 1862 versus relates palaeotropical species the first example of close relations between species with a different number of main head pores among Chydoridae (Crustacea: Anomopoda). Arthropoda Selecta, 8(3): 131-148.

SMIRNOV, N. N., 1998, A revision of the genus Camptocercus (Anomopoda, Chydoridae, Aloninae) Hydrobiologia, 386: 63-83.

SMIRNOV, N. N., 1996, Cladocera: the Chydorinae and Sayciinae (Chydoridae) of the world. Guides to the identification of the microinvertebrates of the continental waters of the world. SPB Academic Publishing. Netherlands., $197 \mathrm{p}$.

SMIRNOV, N. N., 1974, Fauna of the U.S.S.R. Crustacea. Chydoridae. Vol. 1, n. 2. Israel Program for Scientific Translations, Jerusalem, 644p.

SMIRNOV, N. N. \& TIMMS, B. V., 1983, A revision of the Australian Cladocera (Crustacea). Records of the Australian Museum. Supplement 1, 132p.

WHITESIDE, M. C., 1970, Danish Chydorid Cladocera: modern ecology and core studies. Ecol. Monogr., 40: 79-118.

WISNIEWSKI, M., ROCHA, O. \& MATSUMURATUNDISI, T., 2001, First record of Alona setigera Brehm, (Cladocera, Chydoridae) in the neotropical region. Rev. Bras. Biol. 61(4): 701-702. São Carlos.

YOUNG, P. S., 1998, Catalogue of Crustacea of Brazil. Série livros 6, Museu Nacional, Rio de Janeiro, 717p. 